\title{
Protein oxidation and subsequent changes in chicken breast and thigh meats during long-term frozen storage
}

\author{
Eda Demirok Soncu \\ Faculty of Engineering, Department of Food Engineering, Ankara University, Ankara, Turkey \\ e-mail: edemirok@eng.ankara.edu.tr
}

\begin{abstract}
In this study, protein oxidation and subsequent changes were evaluated during the long-term frozen storage of chicken meat cuts. Boneless and skinless chicken breast and thigh meat cuts were packaged, frozen, and stored at $-18^{\circ} \mathrm{C}$ for 6 months, whereas physicochemical analysis and electrophoretic protein profile were evaluated every 1 month. In breast and thigh meats, carbonyl content was noted to increase, whereas sulphydryl content decreased during frozen storage $(p<0.05)$. A significant decrease in protein solubility and water holding capacity $(p<0.05)$ was also determined due to denaturation and aggregation of proteins as a result of protein oxidation. Myofibrillar proteins, particularly myosin heavy chain, were identified to be more susceptible to oxidation although no notable changes were determined in sarcoplasmic protein pattern. In general, significant proteolytic changes were particularly noted from the third month of storage onward. This could be a useful finding in order to make a decision for shelf life and thus minimize undesirable quality changes in chicken meats. Additionally, strong correlations were noted between the examined quality parameters.
\end{abstract}

Key words: chicken meat, carbonyl, sulphydryl, protein solubility, water holding capacity, SDS-PAGE

\section{Introduction}

Chicken meat has been identified to play a key role in human nutrition due to its higher protein content and other valuable nutrients (Adeyemi et al. 2014). Production rate of poultry meat varies from year over year. Its annual production growth has been reported to be at 3.06 ton for 2018, and that for 2019, 2020, and 2021, it was estimated to be at $2.15,1.79$, and 1.56 ton, respectively (OECD/FAO 2018). Along with this higher production rate, freezing has been identified as the most common and efficient way to protect the quality of the meat, especially when it is yet to be consumed or processed (Alarcon-Rojo and Janacua-Vidales 2010, Adeyemi et al. 2014). Freezing is frequently applied in industry, household conditions and during transportation of chicken meat to all region of the world.

Although the main goal of freezing is to prevent microbial spoilage and mitigation of biochemical reactions, varying quality losses can still occur depending on process conditions (Alarcon-Rojo and Janacua-Vidales 2010, Utrera and Estévez 2013, Adeyemi et al. 2014, Utrera et al. 2014). These quality changes during freezing process are described in three different stages: freezing, frozen storage, and thawing. In the first stage, formation of ice crystals starts as temperature decreases below the freezing point. As is known, when the water freezes, it expands nearly $9 \%$. This increase in volume forces cells to irreversible flexion, thus resulting in mechanical damage on the cell wall and release of mitochondrial and lysosomal enzymes into the sarcoplasm (deMan 1999, Leygonie et al. 2012, Utrera et al. 2014). These intracellular and extracellular enzymes have been identified as one of the triggering factors for biochemical reactions, such as lipolysis, lipid oxidation, protein denaturation, and protein oxidation (Leygonie et al. 2012, Utrera et al. 2014). Frozen storage should be performed at least $-18^{\circ} \mathrm{C}$ for frozen poultry meats according to the European and international regulations (Alarcon-Rojo and Janacua-Vidales 2010, Utrera et al. 2014). Small amount of unfrozen water can still persist at this temperature, which might induce the biochemical reactions. Lipids are oxidized into primary oxidation products. Protein solubility decreases, and proteins lost their functions due to degradation, denaturation/aggregation, and oxidation reactions, which results in quality loss in textural and sensory attributes (Leygonie et al. 2012). As for the third stage, formation of secondary lipid oxidation products, varying amounts of thaw loss, surface microbial growth, and loss of nutritional components are the negative impacts of thawing on the quality of frozen meat products (Alarcon-Rojo and JanacuaVidales 2010, Leygonie et al. 2012).

From the past up until today, a number of studies were already conducted to determine the quality changes in different meat types under frozen conditions (Benjakul et al. 1997, Baron et al. 2007, Chan et al. 2011, Utrera and Estévez 2013, Utrera et al. 2014). In a previous study performed by Lee et al. (2008), frozen chicken breast fillets 


\section{AGRICULTURAL AND FOOD SCIENCE}

E.D. Soncu (2020) 29: 505-514

were stored at $-18^{\circ} \mathrm{C}$ for up to 8 months. Thaw loss and cooking loss consistently increased during storage, while the moisture content of cooked meats started to decrease after 2 months. The meat, which was stored longer time, was noted to be darker, redder, and less yellow color. Tenderness significantly decreased between 2 and 4 months; therefore, researchers suggested that frozen breast fillets should be consumed within 2 months. In another study, Utrera and Estévez (2013) reported that protein oxidation was induced by frozen storage $\left(20\right.$ weeks, $\left.-18^{\circ} \mathrm{C}\right)$ in chicken meats. In a study conducted to examine the effect of different freezing temperatures $\left(-7,-12\right.$, and $\left.-18^{\circ} \mathrm{C}\right)$, frozen chicken breast and leg meat were stored at $-18^{\circ} \mathrm{C}$ for 6 months. Although different freezing temperatures did not affect lipid oxidation in chicken meats, freezing at $-7^{\circ} \mathrm{C}$ resulted in a significant increase in carbonyl content and a significant decrease in sulphydryl groups after 3 months of storage. On the other side, it was emphasized that lipid and protein oxidation were more intense in leg meat as compared to breast meat (Soyer et al. 2010).

Determining the changes in protein structure, which are observed during the freezing process, is considered of utmost importance, since they can affect other crucial properties of meat such as its yield, texture, sensory attributes, eating quality, and emulsification or marination properties for further processing. With that said, examining these proteolytic changes in detail will be useful for the poultry industry in order to understand the effect of long-term frozen storage and provide further knowledge in terms of shelf life and production of high-quality meats and meat products. Among these proteolytic changes, protein oxidation has been identified as the most crucial part during frozen storage of meat, since it can negatively affect the functionality of proteins, such as its solubility and water holding capacity (Estevez 2011, Leygonie et al. 2012). From this point of view, this current study was designed to determine protein oxidation and subsequent changes in chicken breast and thigh meats during longterm frozen storage via analyzing its physicochemical and electrophoretic properties. In addition, determination of the correlations between the studied parameters was aimed.

\section{Materials and methods}

\section{Materials, sample preparation, and storage}

24 hour post-mortem boneless-skinless chicken breast meat (Pectoralis major) and chicken thigh meat (Quadriceps femoris) were purchased from a commercial facility in Turkey. The meat cuts were obtained from broilers (Ross 308) grown at the same farm. The meats were immediately transferred to a laboratory under cold chain. After visible fats and connective tissues were trimmed, both the left and right halves of breast meat (approximately $500 \mathrm{~g}$ ) were placed together into polypropylene packaging pouches as a monolayer. The pouch was then sealed aerobically. As for chicken thigh meat, three pieces (approximately $500 \mathrm{~g}$ ) were packaged under the same conditions. A total of seven pouches were individually prepared for both breast and thigh meats. After one pouch was separated for fresh meat analysis (month 0 ), six pouches were rapidly frozen until the internal temperature of the package reached $-18{ }^{\circ} \mathrm{C}$. The pouches were later stored in freezer at $-18{ }^{\circ} \mathrm{C}$ for 6 months. Every month, one pouch was periodically removed from the freezer and thawed under refrigerated condition at $4 \pm 1{ }^{\circ} \mathrm{C}$ for 16 hours in order to perform quality analysis in the freeze-thawed samples. Experiment was replicated in two different times with different meat cuts, and duplicate analysis per replication was done in homogenized samples prepared using meat grinder (Arnica Promeat W2000 Grande, Turkey).

\section{Evaluation of protein oxidation}

\section{Quantification of carbonyl compounds}

Protein carbonyls, which has been considered an indicator of protein oxidation, were determined in both fresh and freeze-thawed samples according to the DNPH (2,4-dinitrophenylhydrazine) method outlined by Zakrys et al. (2008). Approximately $1 \mathrm{~g}$ of sample was homogenized using $10 \mathrm{ml}$ of $0.15 \mathrm{M} \mathrm{KCl}$, and then $100 \mu \mathrm{l}$ homogenate was transferred to four Eppendorf tubes. After adding $1 \mathrm{ml}$ of trichloroacetic acid (TCA, 10\% w/v) into the tubes to precipitate proteins, two of these eppendorf tubes were mixed with $1 \mathrm{ml}$ of $0.2 \% \mathrm{DNPH}$ (prepared in $2 \mathrm{M} \mathrm{HCl}$ ) for carbonyl measurement, while the other two tubes were mixed with $1 \mathrm{ml}$ of $2 \mathrm{M} \mathrm{HCl}$ to determine protein concentration. Upon incubation for $1 \mathrm{~h}$, the samples were firstly treated with $1 \mathrm{ml}$ of $10 \%$ TCA, followed by a mixture of ethanol/ethyl acetate $(1: 1, \mathrm{v} / \mathrm{v}, 1 \mathrm{ml})$ to remove lipid residues. After centrifugation, the pellet was dried under nitrogen, and $1.5 \mathrm{ml}$ of $6 \mathrm{M}$ guanidine- $\mathrm{HCl}$ (prepared in $20 \mathrm{mM}$ potassium phosphate buffer, $\mathrm{pH}$ 6.5) was added to the tubes. Samples prepared for carbonyl quantification were read at $370 \mathrm{~nm}$ (UV-VIS spectrophotometer Lambda 35 , Perkin Elmer) against guanidine- $\mathrm{HCl}$ as a blank. Those for protein concentration were read at $280 \mathrm{~nm}$ against a standard curve of bovine serum albumin prepared in guanidine- $\mathrm{HCl}$. The results were then calculated as nmol $\mathrm{mg}^{-1}$ protein using an extinction coefficient of $21 \mathrm{mM}^{-1} \mathrm{~cm}^{-1}$ for protein hydrozones. 


\section{AGRICULTURAL AND FOOD SCIENCE}

E.D. Soncu (2020) 29: 505-514

\section{Quantification of sulphydryl groups}

The total free sulphydryl groups of fresh and freeze-thawed samples were determined by reacting with 5,5'-dithiobis(2-nitrobenzoic acid) (DTNB) as described by Srinivasan and Hultin (1997). To prepare the samples for spectrophotometric reading, $1 \mathrm{~g}$ of meat was homogenized in $20 \mathrm{ml}$ of $0.05 \mathrm{M}$ phosphate buffer $(\mathrm{pH}=7.2)$ and diluted with $0.05 \mathrm{M}$ phosphate buffer $(\mathrm{pH}=7.2$, including $0.6 \mathrm{M} \mathrm{NaCl}, 6 \mathrm{mM}$ EDTA, $8 \mathrm{M}$ urea) in the ratio of 1:9 (v/v). After centrifugation at $14000 \mathrm{~g}$ for $20 \mathrm{~min}$ at $4{ }^{\circ} \mathrm{C}, 1.5 \mathrm{ml}$ of supernatant was mixed with $0.02 \mathrm{ml}$ of DTNB (0.01 M, prepared in $0.05 \mathrm{M}$ sodium acetate) as a sample cuvette. For reference cuvette, $0.02 \mathrm{ml}$ of $0.05 \mathrm{M}$ sodium acetate was added into $1.5 \mathrm{ml}$ of supernatant. After incubation at $40{ }^{\circ} \mathrm{C}$ for $15 \mathrm{~min}$, samples were read at $420 \mathrm{~nm}$ (UV-VIS spectrophotometer Lambda 35, Perkin Elmer). The results were then calculated as $\mathrm{nmol} \mathrm{mg}^{-1}$ protein using a molar extinction coefficient of $11400 \mathrm{M}^{-1} \mathrm{~cm}^{-1}$ by subtracting the absorbance of reference from that of the sample.

\section{Determination of protein solubility}

To determine the total protein solubility (TPS) and sarcoplasmic protein solubility (SPS), individual extracts from fresh and freeze-thawed samples were obtained according to the procedure of Farouk and Swan (1998). Biuret method (Gornall et al. 1949) was used to measure protein concentration in the extracts, and the results were expressed as percentage of meat (g/100 g). Myofibrillar protein solubility was also calculated by subtracting the SPS\% from TPS\%.

\section{Water holding capacity}

Water holding capacity (WHC) could be considered as a tool to directly measure protein oxidation in meat. A procedure of Hsieh et al. (2010) was used to determine WHC in fresh and freeze-thawed samples. Approximately 10 $\mathrm{g}$ of meat sample $\left(\mathrm{P}_{0}\right)$ was weighed into the tube and centrifuged at $3000 \mathrm{~g}$ for $20 \mathrm{~min}$ at $4{ }^{\circ} \mathrm{C}$. Upon centrifugation, exudate was filtered, and the meat was weighed after drying $\left(P_{m}\right)$. The results were calculated using the following formula and expressed as percentage (\%). The moisture contents were measured by drying the samples at $105^{\circ} \mathrm{C}$ for 16 hours (AOAC 2010).

$W H C=\left[1-\left(\frac{P o-P m}{P m}\right) \times\right.$ water content $] \times 100$

\section{Protein electrophoresis by SDS-PAGE}

\section{Protein extraction}

In the first step, in order to perform sarcoplasmic protein extraction, $10 \mathrm{~g}$ of fresh or freeze-thawed samples was homogenized in $40 \mathrm{ml}$ of $0.03 \mathrm{M}$ potassium phosphate buffer $(\mathrm{pH}=7.4)$ for 1 min using an Ultra-Turrax (Miccra D9, Germany). The homogenate was centrifuged at $12000 \mathrm{~g}$ for $20 \mathrm{~min}$ at $4{ }^{\circ} \mathrm{C}$ (Hermle Z326K, Germany), and the supernatant was filtered through glasswool into the amber glass bottle. The same procedure was applied to pellet once more, and the supernatants were combined. As for myofibrillar protein extraction, the pellet was resuspended in $40 \mathrm{ml}$ of $8 \mathrm{M}$ urea buffer (including $1 \% \beta$-mercaptoethanol), and the suspension was centrifuged at $12000 \mathrm{~g}$ for $20 \mathrm{~min}$ at $4{ }^{\circ} \mathrm{C}$. The supernatant was then filtered through glasswool into another amber glass bottle (Candogan 2000).

\section{Determination of protein concentration and sample preparation}

Protein concentration of sarcoplasmic and myofibrillar extracts was quantified spectrophotometrically using Bradford Reagent (Sigma-Aldrich \#B6916). For this quantification, sarcoplasmic and myofibrillar extracts were diluted using $0.03 \mathrm{M}$ potassium phosphate buffer and $8 \mathrm{M}$ urea buffer, respectively, and then, $50 \mu$ of diluted extract and $1.5 \mathrm{ml}$ of Bradford Reagent were mixed in a cuvette. The mixture was then left to incubate at room temperature for $30 \mathrm{~min}$. The absorbance was read at $595 \mathrm{~nm}$ using a UV/VIS spectrophotometer (Perkin-Elmer Lambda 35, USA). The results were calculated using a standard curve prepared by bovine serum albumin.

As for the sample preparation, the protein concentration of sarcoplasmic and myofibrillar extracts was adjusted to $0.75 \mathrm{mg} \mathrm{ml}^{-1}$ using a Laemmli sample buffer. The buffer was prepared by mixing $3 \mathrm{ml}$ of distilled water, $1 \mathrm{ml}$ of $0.5 \mathrm{M}$ Tris- $\mathrm{HCl}$ (pH 6.8), $1.6 \mathrm{ml}$ of glycerol, $1.6 \mathrm{ml}$ of $10 \%$ sodium dodecyl sulfate (SDS), $0.4 \mathrm{ml}$ of $\beta$-mercaptoethanol, and $0.4 \mathrm{ml}$ of $0.5 \%$ bromophenol blue in water (Laemmli 1970). After mixing the required amount of extract and buffer, the mixture was vortexed and incubated at $95^{\circ} \mathrm{C}$ for $10 \mathrm{~min}$. The samples were kept at $4{ }^{\circ} \mathrm{C}$ until loading stage. 
SDS-PAGE gel preparation, sample loading, and protein separation

Prior to gel preparation, glass plates were assembled on the casting stand. Then, $12 \%$ separating gel solution was prepared and immediately placed into the glass plates up to $5 \mathrm{~cm}$. Ethanol (70\%) was used to fill the upper side of the plates in order to remove the bubbles and provide smooth surface. The gel was allowed to polymerization for $30 \mathrm{~min}$ at room temperature. After the ethanol was removed, the glass plates were filled with the $4 \%$ stacking gel up to the upper side, and a 10-well comb was gently inserted. The gel was then left to polymerize for $30 \mathrm{~min}$.

In respect to sample loading, $5 \mu$ l of prestained broad range (Bio-Rad \#161-0318) protein marker was loaded into the first well, followed by $30 \mu$ l loading of samples into the remaining wells. Protein separation was carried out in running buffer (25 Mm Tris base, $192 \mathrm{mM}$ glycine, and 0.1\% SDS at pH 8.3) under constant amper of $32 \mathrm{~mA}$ using a Mini-Protean III Cell and PowerPac Basic power supply (Bio-Rad, USA). The electrophoresis was completed when the tracking dye reached the bottom side of the gel. After the gels were removed from the glass plates, they were stained using the Coomassie brilliant blue solution ( $1 \mathrm{~g} \mathrm{l}^{-1}$ in methanol/acetic acid/distilled water (5:1:4) mixture) by stirring for $30 \mathrm{~min}$. As for destaining, a mixture of methanol/acetic acid/distilled water (2:1:17) was used. The molecular weights (MW) of protein bands were then calculated according to their relative mobility using a standard curve, which was plotted by the molecular weight of each marker against its relative mobility.

\section{Statistical analysis}

One-way ANOVA for randomized block design and Tukey's comparison test were used to determine the significance of "periods of storage time (month $0,1,2,3,4,5,6)$ " on the quality parameters examined. Minitab 16 Statistical Software was used for both variance and correlation analyses. All data are shown as mean values \pm standard error of the mean.

\section{Results and discussion}

\section{Evaluating the protein oxidation in chicken breast meat and chicken thigh meat}

The main pathway for protein carbonylation in meat is known as metal ion-catalyzed oxidation of side chains of some sensitive amino acids such as lysine, threonine, arginine and proline. The routine DNPH method is generally used for the quantification of carbonyl compounds in meats, and our results have been summarized in Tables 1 and 2 for chicken breast and chicken thigh meats, respectively. The carbonyl content of fresh breast meat was deter-

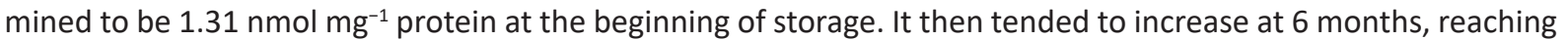
$2.19 \mathrm{nmol} \mathrm{mg}^{-1}$ protein at the end of storage $(p<0.05)$. The same trend was also seen for thigh meats. Its carbonyl content increased from 1.04 to $2.36 \mathrm{nmol} \mathrm{mg}^{-1}$ protein during 6 months of storage. Consistent with our results, in previous studies, it was reported that frozen storage induced carbonyl formation in turkey breast meat (Chan et al. 2011), fish (Lund et al. 2011), pork, beef, and chicken meat patties (Utrera and Estévez 2013, Utrera et al. 2014).

Oxidation of sulphydryl groups has been determined to result in the formation of various oxidation products, such as sulfenic acid, sulfinic acid, and disulfide cross-links. The loss of sulphydryl groups in meat is measured by Ellman's reagent method (Lund et al. 2011), and our results are presented in Table 1 for breast meat and in Table 2 for thigh meat. The initial sulphydryl content was determined to be 67.09 and $50.95 \mathrm{nmol} \mathrm{mg}^{-1}$ protein in breast and thigh meats, respectively. The sulphydryl groups were then observed to gradually decrease during the entire storage duration; however, a sharp decrease was especially observed in the third month $(p<0.05)$. Approximately $43.6 \%$ of total sulphydryl content were lost in chicken breast meat from the beginning to third month of storage, whereas for chicken thigh meat, it was calculated to be $58.4 \%$. As for the last month of storage, the lowest sulphydryl content was determined to be 10.50 and $4.36 \mathrm{nmol} \mathrm{mg}{ }^{-1}$ protein for breast and thigh meats $(p<0.05)$, respectively. The decrease in the sulphydryl content of chicken meat cuts during frozen storage could be explained by denaturation and aggregation of muscle proteins due to oxidation of thiol groups in cysteine or disulfide interchange reactions, which take place between polypeptides or within polypeptides (Xia et al. 2009). Consistent with our results, significant decrease for reactive and total sulphydryl groups was also reported in turkey breast meat stored at $-30^{\circ} \mathrm{C}$ for 3 weeks (Chan et al. 2011). Benjakul et al. (1997) observed that sulphydryl content of carp actomyosin decreased, especially after 3 days of iced storage.

In brief, carbonyl content was noted to increase, whereas sulphydryl groups decreased in chicken meats during the long-term frozen storage as in line with theoretical knowledge. Moreover, these changes were determined to be dependent on the period of storage. This finding was consistent with the report of Soyer et al. (2010) who 
Table 1. Changes in the protein pattern of chicken breast meat within 6 months of frozen storage $(n=2)$

\begin{tabular}{|c|c|c|c|c|c|c|c|}
\hline Months & $\begin{array}{l}\text { Carbonyl content } \\
\text { (nmol mg } \text { (n }^{-1} \text { protein) }\end{array}$ & $\begin{array}{l}\text { Sulphydryl content } \\
\text { (nmol mg } \text { mprotein) }^{-1}\end{array}$ & $\begin{array}{l}\text { Total protein solubility } \\
(\%)\end{array}$ & $\begin{array}{l}\text { Sarcoplasmic protein } \\
\text { solubility (\%) }\end{array}$ & $\begin{array}{l}\text { Myofibrillar protein } \\
\text { solubility (\%) }\end{array}$ & $\begin{array}{l}\text { Water holding } \\
\text { capacity (\%) }\end{array}$ & $\begin{array}{c}\text { Moisture content } \\
(\%)\end{array}$ \\
\hline MO (FM) & $1.31 \pm 0.05^{b}$ & $67.09 \pm 8.62^{\mathrm{a}}$ & $45.37 \pm 2.95^{\mathrm{a}}$ & $18.55 \pm 0.28^{\mathrm{a}}$ & $26.83 \pm 3.23$ & $96.35 \pm 0.65$ & $74.03 \pm 0.83$ \\
\hline M1 & $2.14 \pm 0.07^{a b}$ & $63.20 \pm 6.53^{\mathrm{a}}$ & $38.44 \pm 0.51^{\mathrm{ab}}$ & $11.69 \pm 1.37^{\mathrm{ab}}$ & $26.75 \pm 0.86$ & $94.83 \pm 1.62$ & $73.48 \pm 0.64$ \\
\hline M2 & $2.51 \pm 0.20^{\mathrm{a}}$ & $61.23 \pm 4.65^{\mathrm{a}}$ & $34.31 \pm 0.36^{\mathrm{bc}}$ & $12.90 \pm 0.26^{\mathrm{ab}}$ & $21.42 \pm 0.62$ & $93.46 \pm 1.46$ & $74.40 \pm 0.19$ \\
\hline M3 & $2.47 \pm 0.07^{\mathrm{a}}$ & $37.81 \pm 3.21^{\mathrm{b}}$ & $28.95 \pm 0.53^{c}$ & $9.21 \pm 0.45^{b}$ & $19.74 \pm 0.08$ & $92.36 \pm 0.29$ & $73.98 \pm 0.72$ \\
\hline M4 & $2.05 \pm 0.27^{\mathrm{ab}}$ & $28.32 \pm 0.75^{b c}$ & $29.05 \pm 0.34^{c}$ & $10.21 \pm 1.09^{b}$ & $18.84 \pm 0.75$ & $93.19 \pm 0.11$ & $75.10 \pm 0.67$ \\
\hline M5 & $1.90 \pm 0.14^{\mathrm{ab}}$ & $32.78 \pm 0.96^{b}$ & $31.06 \pm 0.40^{b c}$ & $10.77 \pm 2.82^{\mathrm{b}}$ & $20.29 \pm 2.42$ & $91.26 \pm 2.16$ & $73.10 \pm 0.83$ \\
\hline M6 & $2.19 \pm 0.14^{\mathrm{a}}$ & $10.50 \pm 0.14^{c}$ & $30.45 \pm 1.16^{c}$ & $11.19 \pm 1.96^{\mathrm{ab}}$ & $19.25 \pm 3.13$ & $91.12 \pm 0.90$ & $73.26 \pm 0.02$ \\
\hline$p$-value & 0.011 & 0.000 & 0.001 & 0.024 & 0.122 & 0.207 & 0.348 \\
\hline
\end{tabular}

M3 = 3-month-old frozen sample; M4 = 4-month-old frozen sample; M5 = 5-month-old frozen sample; M6 = 6-month-old frozen sample

Table 2. Changes in the protein pattern of chicken thigh meat within 6 months of frozen storage $(n=2)$

\begin{tabular}{|c|c|c|c|c|c|c|c|}
\hline Months & $\begin{array}{l}\text { Carbonyl content } \\
\text { (nmol mg } \text { mprotein) }^{-1}\end{array}$ & $\begin{array}{l}\text { Sulphydryl content } \\
\text { (nmol mg } \text { mprotein) }^{-1}\end{array}$ & $\begin{array}{l}\text { Total protein solubility } \\
\text { (\%) }\end{array}$ & $\begin{array}{l}\text { Sarcoplasmic protein } \\
\text { solubility (\%) }\end{array}$ & $\begin{array}{l}\text { Myofibrillar protein } \\
\text { solubility (\%) }\end{array}$ & $\begin{array}{l}\text { Water holding } \\
\text { capacity (\%) }\end{array}$ & $\begin{array}{c}\text { Moisture content } \\
(\%)\end{array}$ \\
\hline MO (FM) & $1.04 \pm 0.44$ & $50.95 \pm 1.04^{\mathrm{a}}$ & $44.60 \pm 2.62^{\mathrm{a}}$ & $16.24 \pm 0.61^{\mathrm{a}}$ & $28.35 \pm 3.22^{\mathrm{a}}$ & $98.33 \pm 0.09^{a}$ & $68.23 \pm 0.41$ \\
\hline M1 & $1.35 \pm 0.01$ & $52.98 \pm 2.64^{\mathrm{a}}$ & $37.92 \pm 0.34^{\mathrm{ab}}$ & $10.26 \pm 0.49^{b}$ & $27.66 \pm 0.15^{\mathrm{a}}$ & $95.64 \pm 0.18^{\mathrm{ab}}$ & $67.93 \pm 0.04$ \\
\hline M2 & $1.78 \pm 0.24$ & $52.51 \pm 2.16^{\mathrm{a}}$ & $33.05 \pm 1.37^{\mathrm{ab}}$ & $9.08 \pm 0.06^{b}$ & $23.97 \pm 1.31^{\mathrm{a}}$ & $94.69 \pm 0.42^{\mathrm{ab}}$ & $69.31 \pm 0.41$ \\
\hline M3 & $1.69 \pm 0.16$ & $21.18 \pm 1.87^{b}$ & $28.85 \pm 0.53^{b}$ & $9.92 \pm 0.38^{b}$ & $18.93 \pm 0.15^{\mathrm{a}}$ & $94.47 \pm 1.59^{\mathrm{ab}}$ & $68.97 \pm 1.12$ \\
\hline M4 & $1.72 \pm 0.39$ & $14.77 \pm 0.28^{b}$ & $28.48 \pm 0.68^{\mathrm{b}}$ & $11.61 \pm 0.69^{b}$ & $16.88 \pm 0.01^{\mathrm{a}}$ & $94.18 \pm 0.70^{\mathrm{ab}}$ & $67.99 \pm 0.01$ \\
\hline M5 & $1.61 \pm 0.40$ & $20.90 \pm 0.95^{b}$ & $29.83 \pm 0.90^{\mathrm{b}}$ & $11.25 \pm 1.22^{\mathrm{b}}$ & $18.58 \pm 2.12^{\mathrm{a}}$ & $92.68 \pm 0.39^{b}$ & $67.67 \pm 0.21$ \\
\hline M6 & $2.36 \pm 0.44$ & $4.36 \pm 0.04^{c}$ & $28.45 \pm 5.23^{b}$ & $10.60 \pm 1.20^{b}$ & $17.85 \pm 4.02^{\mathrm{a}}$ & $92.87 \pm 0.37^{b}$ & $68.71 \pm 0.10$ \\
\hline$p$-value & 0.408 & 0.000 & 0.022 & 0.006 & 0.050 & 0.018 & 0.288 \\
\hline
\end{tabular}

M3 = 3-month-old frozen sample; M4 = 4-month-old frozen sample; M5 = 5-month-old frozen sample; M6 = 6-month-old frozen sample 


\section{AGRICULTURAL AND FOOD SCIENCE}

E.D. Soncu (2020) 29: 505-514

emphasized that the duration of frozen storage can have a significant impact on protein oxidation in chicken meat, which resulted in a cumulative increase in carbonyls and gradual decrease in sulphydryls during 6 months of frozen storage. They also reported that leg meat was more sensitive to oxidation as compared to breast meat. Our results were also consistent with this finding. From the beginning and end of storage, breast meat lost $84 \%$ of total sulphydryl, while for the thigh meat cut, the reduction was estimated to be at $91 \%$. As for carbonyl content, a $67 \%$ increase was determined for breast meat, while thigh meat recorded a two fold increase. As stated by Lombardi-Boccia et al. (2002), chicken thigh meat had higher heme iron content than chicken breast meat. Heme iron has been identified as an initiator for protein carbonylation in meat system. Heme iron is also responsible for metal ion-catalyzed oxidation of side chains of some sensitive amino acids such as lysine, threonine, arginine, and proline (Lund et al. 2011, Utrera and Estévez 2013). In line with this postulation, higher rate of carbonyl formation in chicken thigh meat could be directly associated to its higher heme iron content as similarly stated by Utrera and Estévez (2013).

Results regarding protein solubility of chicken meat cuts are presented in Tables 1 and 2. The initial TPS and SPS in fresh breast meat were found to be $45.37 \%$ and $18.55 \%$, respectively. At the end of frozen storage, TPS and SPS were observed to significantly decrease to $30.45 \%$ and $11.19 \%$, respectively $(p<0.05)$. Similarly, MPS decreased from $26.83 \%$ to $19.25 \%$; however, this reduction was not found to be statistically significant $(p>0.05)$. When the reduction in protein solubility was examined in storage periods, the lowest TPS (28.95\%) and SPS (9.21\%) values were determined in the third month. This finding demonstrated that a decrease in protein solubility was revealed to a great extent during the first 3 months of frozen storage. For thigh meats, a significant decrease in TPS (from $44.60 \%$ to $28.45 \%$ ), SPS (from $16.24 \%$ to $10.60 \%$ ), and MPS (from $28.35 \%$ to $17.85 \%$ ) was also determined during the entire storage $(p<0.05)$. Like in breast meat, this reduction was noted to substantially occur during the first 2 months for SPS and during the first 3 months for TPS and MPS. As a general evaluation, the decrease in protein solubility is mainly associated with the formation of cross-links by disulfide bonds due to protein denaturation (Chan et al. 2011, Adeyemi et al. 2014). In this present study, the total TPS decrease was calculated to be $33 \%$ and $36 \%$ for breast and thigh meat, respectively, during the entire storage. This observation was found to be consistent with the finding of Chan et al. (2011) who reported that freezing could result in $33 \%$ reduction in TPS for turkey breast meat.

WHC has been defined as the ability of meat to retain its moisture when external forces are applied (Van Laack 1999). The initial WHC was found to be $96.35 \%$ for fresh breast meat and $98.33 \%$ for fresh thigh meat. WHC of both chicken meat cuts was observed to gradually decrease during frozen storage due to significant effect of protein oxidation and cell damage. During the entire storage, the reduction in WHC of breast meat was calculated at $5.4 \%(p>0.05)$, whereas for thigh meat, it was $5.6 \%$, which was statistically significant $(p<0.05)$. This finding has confirmed that thigh meat was more prone to protein oxidation as compared to breast meat. Consistent with our findings, WHC of ostrich meat and beef were also noted to significantly decrease during six months of frozen storage (Alasvand Zarasvand et al. 2013). In another study, higher thaw or cook loss and lower water content pointed out that WHC significantly decreased in breast fillets during 8 months of frozen storage (Lee et al. 2008). Furthermore, Utrera et al. (2014) reported that higher reduction was observed in WHC of beef patties stored at $-18^{\circ} \mathrm{C}$ as compared with those stored at $-80^{\circ} \mathrm{C}$ due to higher degree of protein oxidation.

In meat systems, great amount of water is bound by myofibrils, which means myofibrillar proteins are responsible for the WHC of meat (Huff-Lonergan and Lonergan 2005). On the other hand, proteolytic changes induced by oxidation in the frozen state can have negative impact on WHC. For instance, protein denaturation (Ali et al. 2015) or reduced swelling of myofibrils due to protein cross-links and aggregation (Bao et al. 2018) or shrinkage of inter-filamental spaces as a result of aggregation and coagulation in myosin and actin (Leygonie et al. 2012) are directly associated with reduction in WHC. As a consequence of these undesirable changes in protein structure, the water remained unattached to myofibrils due to their low WHC, and varying amount of moisture lost can occur during thawing.

The moisture contents of both chicken breast and thigh meat cuts have been provided in Tables 1 and 2, respectively. No significant differences were noted during the different periods of storage time. Although denaturation and oxidation of proteins induced the decrease in WHC of chicken meats, significant amount of moisture loss did not occur in breast and thigh meat within the 6 months of frozen storage.

\section{SDS-PAGE profile of chicken breast meat and chicken thigh meat}

The sarcoplasmic and myofibrillar protein profiles of chicken meat cuts have been provided in Figures 1 and 2, respectively. In both figures, from left to right, first gel image includes marker and second gel image demonstrates 
protein profile of fresh breast meat and fresh thigh meat, respectively. Third and subsequent gel images present the protein profile of frozen chicken breast and thigh meats during six months of storage with one month interval.

As seen in Figure 1, the breast and thigh meat cuts have been observed to have the same sarcoplasmic protein profile except for the 1st, 2nd, and 4th bands, which were noted to be more intense in breast meat when compared to thigh meat, for gels M0, M1, and M2. Additionally, the sarcoplasmic protein pattern of breast meat was found to be consistent with the findings of previous researchers (Adeyemi et al. 2014, Ali et al. 2015). In fresh meats, 11 bands were determined as follows: the first band with an estimated MW of $114 \mathrm{kDa}$; the second and third bands with MW of 82 and $74 \mathrm{kDa}$, respectively; followed by five bands with MW between 55 and $40 \mathrm{kDa}$; and then the last three bands with a MW of 28, 24, and $21 \mathrm{kDa}$, respectively. The same sequence was also observed from the first gel of frozen samples onward. During the first two months of frozen storage, the sarcoplasmic protein profile of chicken meat cuts did not seem to differ; however, some significant changes were determined at the end of third month. As demonstrated in gels M3, M4, M5, and M6, the same protein bands were seen, but their intensity decreased as a result of oxidation and denaturation reactions as compared to $\mathrm{M} 0, \mathrm{M} 1$, and $\mathrm{M} 2$.

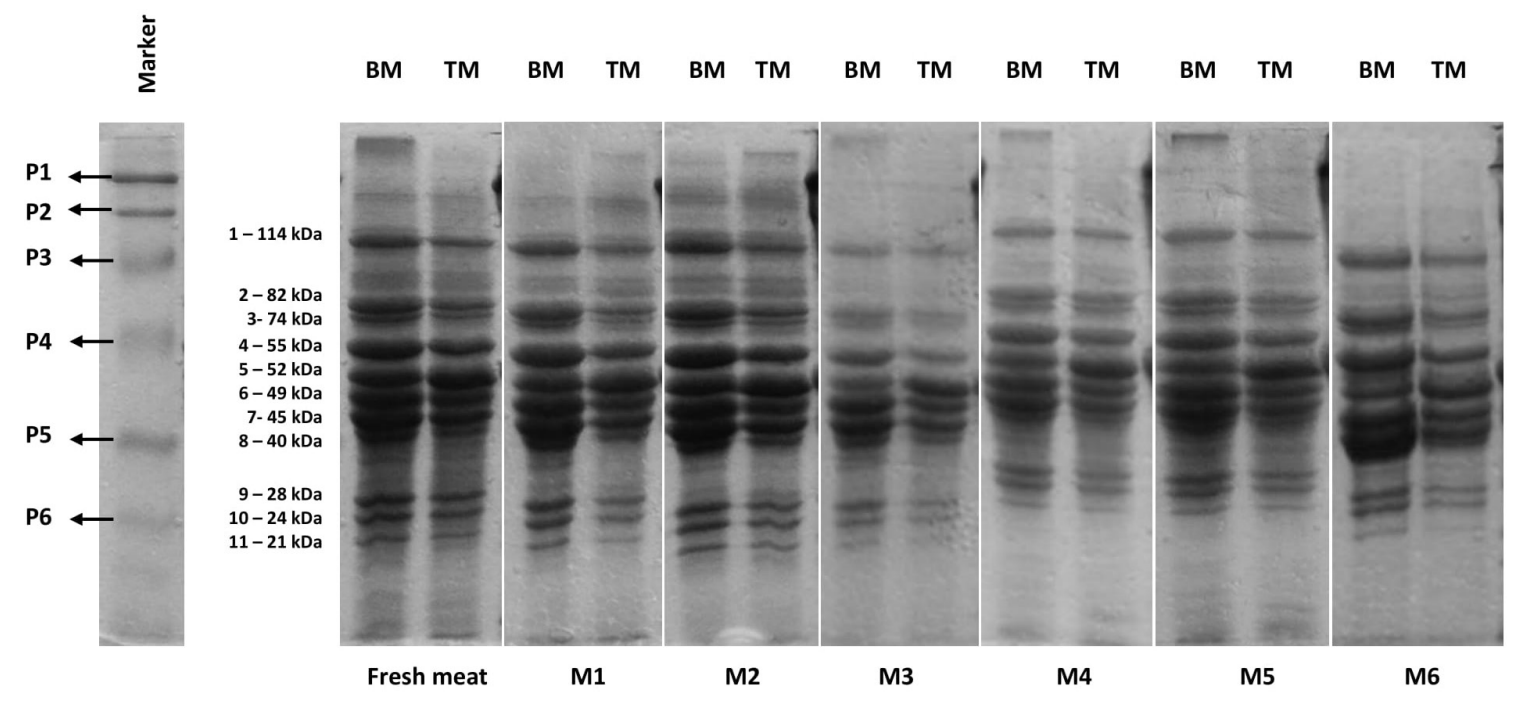

Fig. 1. Sarcoplasmic protein pattern of chicken breast and thigh meat cuts within 6 months of frozen storage (BM = chicken breast meat; $\mathrm{TM}=$ chicken thigh meat; $\mathrm{FM}=$ fresh meat; $\mathrm{M} 1$ = 1-month-old frozen sample; $\mathrm{M} 2$ = 2-monthold frozen sample; M3 = 3-month-old frozen sample; M4 = 4-month-old frozen sample; M5 = 5-month-old frozen sample; M6 = 6-month-old frozen sample; P1 = myosin (202.82 kDa); P2 = $\beta$-galactosidase (115.56 kDa); P3 = bovine serum albumin (98.22 kDa); P4 = ovalbumin (51.37 kDa); P5 = carbonic anhydrase (37.24 kDa); P6 = soybean trypsin inhibitor (29.00 kDa); P7 = lysozyme (19.75 kDa); P8 = aprotinin (6.66 kDa)

As for myofibrillar proteins (Fig. 2), 15 bands were determined in both fresh breast and thigh meat cuts as follows: the first band is myosin heavy chain (MHC) with estimated MW of $200 \mathrm{kDa}$, five bands with MW between 115 and $65 \mathrm{kDa}$, followed by actin with MW of $45 \mathrm{kDa}$, and then eight bands with MW between 42 and $14 \mathrm{kDa}$. As for the first 2 months, the myofibrillar protein sequence of the chicken cuts was found to be similar with that of fresh meat; however, significant changes were observed on the third month of storage onward. The bands, which were aligned between MHC and actin or between actin and a band with MW of $14 \mathrm{kDa}$, reportedly disappeared in the third month. On the next 2 months, three new bands appeared below the actin. And for the last month, two more bands were found right under the actin. This reappearance of bands could be explained by the fragmentation of $\mathrm{MHC}$ as a consequence of proteolysis, since the intensity of MHC started to decrease in the third month and was noted to almost disappear at the end of frozen storage. Similarly, Huang et al. (2015) indicated that frozen storage at $-7^{\circ} \mathrm{C}$ or $-7^{\circ} \mathrm{C} /-18{ }^{\circ} \mathrm{C}$ resulted in the emergence of new bands with a MW of $190 \mathrm{kDa}$ due to myosin fragmentation in dumpling meat fillers. Meanwhile, the disappearance of some bands, fragmentation of MHC, and reduction in its intensity demonstrated that myofibrillar proteins were more susceptible to proteolytic changes during frozen storage as compared to sarcoplasmic proteins. In a similar way, Morzel et al. (2006) reported that myosin was the most affected protein from oxidation. In studies conducted with white muscle, Benjakul et al. (1997) documented that $\mathrm{MHC}$ lost $45 \%$ of its total content in fish within 8 days of iced storage, while Baron et al. (2007) noted that $\mathrm{MHC}$ was oxidized in fish muscle at the beginning of frozen storage at $-20^{\circ} \mathrm{C}$ for 13 months. In another study performed by Lund et al. (2011), myosin and then followed by troponin T were found to be the most sensitive proteins to oxidation. Because lysine, threonine, arginine and proline, which are less durable amino acids to oxidation as previously mentioned, are mainly found in the myofibrillar protein structure. They are identified to be responsible for the sensitivity of myofibrils to protein oxidation (Leygonie et al. 2012). 
On the other hand, in this current study, actin was found to be more durable than myosin against freeze denaturation as similarly mentioned by Alasvand Zarasvand et al. (2013). Consistent with our results, no notable changes were observed for actin in fish within 8 days of iced storage (Benjakul et al. 1997). On the contrary, Baron et al. (2007) indicated that actin was already oxidized at the beginning of frozen storage at $-20^{\circ} \mathrm{C}$ for 13 months as a conclusion of protein cross-links by disulfide bonds and aggregation along with polymerization (Baron et al. 2007, Lund et al. 2011).

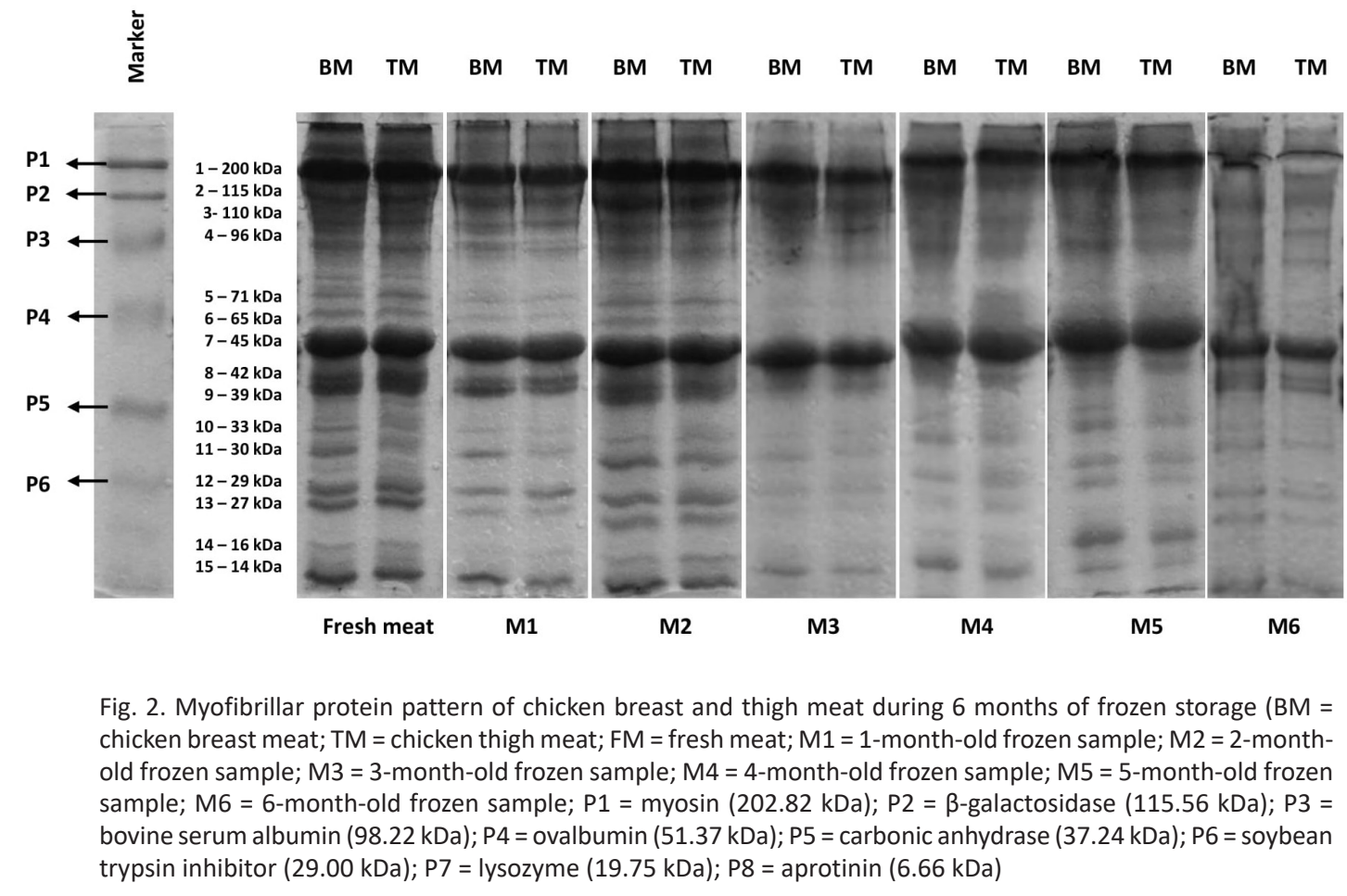

\section{Correlation between quality parameters}

Correlation coefficients among quality parameters have been summarized in Table 3. For chicken breast meat, a negative correlation was determined between carbonyl content and TPS $(-0.61)$ or carbonyl content and SPS $(-0.71)$. This serves as a strong evidence to support the idea that significant increase in carbonyl compounds during frozen storage is associated to significant decreases in TPS and SPS. Similar negative correlation between carbonyls and protein solubility was also observed in minced turkey breast meat stored at $-30^{\circ} \mathrm{C}$ for 3 weeks (Chan et al. 2011) and in tilapia that were stored under aerobic conditions in ice for 14 days (He et al. 2018). This inverse correlation could be explained by protein polymerization and aggregation due to oxidation, which is associated with decreased solubility (Chan et al. 2011, Zhang et al. 2013). On the other hand, sulphydryl groups were found to be highly correlated with TPS (0.72), SPS (0.54), MPS (0.64), and WHC (0.63). Consistently, significant positive correlation between sulphydryls and protein solubility was also reported in tilapia, which was stored aerobically in ice for 14 days (He et al. 2018). This finding serves as an indicator that loss of sulphydryl groups during frozen storage has a linear relationship with the decrease in protein solubility due to cross- linking (Guyon et al. 2016). Moreover, significant correlations were also found between TPS and WHC (0.70) or MPS and WHC (0.70) in breast meat. In a similar study, significant direct relationship between protein solubility and water binding capacity was suggested by Sarma et al. (2000). Researchers reported that reduction in protein solubility can be attributed to the decrease in water binding capacity for sardines stored at $-20^{\circ} \mathrm{C}$ for 12 weeks.

In the current study, similar trend was also observed for chicken thigh meat. Negative correlation $(-0.60)$ between carbonyl content and WHC can be explained by the increasing carbonyl amounts with significant reduction in WHC. As similarly stated by Zhang et al. (2013), changes in WHC were consistent with the increase in protein carbonyls and cross-linkage among both myofibrillar and sarcoplasmic proteins. Additionally, the decrease in TPS and MPS was determined to be highly correlated with the decrease in sulphydryl groups and WHC in thigh meats. As a general evaluation, any negative or positive correlation can demonstrate that the quality parameters, which were examined to evaluate protein oxidation during frozen storage, are strongly interrelated to each other. 
Table 3. Correlation coefficients of quality parameters $(n=2)$

\begin{tabular}{|c|c|c|c|c|c|c|c|}
\hline & & $\begin{array}{l}\text { Sulphydryl groups } \\
\text { (nmol mg-1 protein) }\end{array}$ & $\begin{array}{l}\text { TPS } \\
(\%)\end{array}$ & $\begin{array}{l}\text { SPS } \\
(\%)\end{array}$ & $\begin{array}{l}\text { MPS } \\
(\%)\end{array}$ & $\begin{array}{l}\text { WHC } \\
(\%)\end{array}$ & $\begin{array}{c}\text { Moisture content } \\
(\%)\end{array}$ \\
\hline \multirow{5}{*}{ 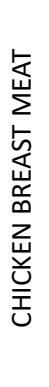 } & $\begin{array}{l}\text { Carbonyl content } \\
\text { (nmol mg } \text { mp }^{-1} \text { protein) }\end{array}$ & NS & $\begin{array}{l}-0.61 \\
(0.020)\end{array}$ & $\begin{array}{l}-0.71 \\
(0.005)\end{array}$ & NS & NS & NS \\
\hline & $\begin{array}{l}\text { Sulphydryl groups } \\
\text { (nmol mg } \text { protein) }^{-1}\end{array}$ & & $\begin{array}{c}0.72 \\
(0.004)\end{array}$ & $\begin{array}{c}0.54 \\
(0.046)\end{array}$ & $\begin{array}{c}0.64 \\
(0.014)\end{array}$ & $\begin{array}{c}0.63 \\
(0.015)\end{array}$ & NS \\
\hline & TPS (\%) & & & $\begin{array}{c}0.79 \\
(0.001)\end{array}$ & $\begin{array}{c}0.85 \\
(0.000)\end{array}$ & $\begin{array}{c}0.70 \\
(0.005)\end{array}$ & NS \\
\hline & SPS (\%) & & & & NS & NS & NS \\
\hline & MPS (\%) & & & & & $\begin{array}{c}0.70 \\
(0.006)\end{array}$ & NS \\
\hline \multirow{7}{*}{  } & WHC (\%) & & & & & & NS \\
\hline & $\begin{array}{l}\text { Carbonyl content } \\
\text { (nmol mg } \text { mp }^{-1} \text { rotein) }\end{array}$ & NS & NS & NS & NS & $\begin{array}{l}-0.60 \\
(0.031)\end{array}$ & NS \\
\hline & $\begin{array}{l}\text { Sulphydryl groups } \\
\text { (nmol mg } \text { mp }^{-1} \text { rotein) }\end{array}$ & & $\begin{array}{c}0.74 \\
(0.002)\end{array}$ & NS & $\begin{array}{c}0.83 \\
(0.000)\end{array}$ & $\begin{array}{c}0.67 \\
(0.009)\end{array}$ & NS \\
\hline & TPS (\%) & & & $0.65(0.01)$ & $\begin{array}{c}0.94 \\
(0.000)\end{array}$ & $\begin{array}{c}0.80 \\
(0.001)\end{array}$ & NS \\
\hline & SPS (\%) & & & & NS & $\begin{array}{c}0.63 \\
(0.016)\end{array}$ & NS \\
\hline & MPS (\%) & & & & & $\begin{array}{c}0.70 \\
(0.005)\end{array}$ & NS \\
\hline & WHC (\%) & & & & & & NS \\
\hline
\end{tabular}

\section{Conclusion}

In this current study, protein oxidation and subsequent changes were determined on primer chicken meat cuts during frozen storage at $-18{ }^{\circ} \mathrm{C}$ for 6 months. Physicochemical analysis indicated that carbonyl compounds increased, whereas sulphydryl amounts, protein solubility, and water holding capacity were observed to decrease, which are considered important indicators of protein oxidation. Considerable changes were determined in electrophoretic pattern of myofibrillar proteins on the third month onward, which was supported by sulphydryl and protein solubility analysis. This finding is considered a break through for the poultry industry; thus, a 3-month shelf life for frozen chicken breast and thigh meat cuts should be suggested in order to minimize undesirable changes in protein structure and provide high-quality freeze-thawed chicken meat.

\section{Acknowledgment}

Appreciation is expressed to Prof. Dr. Nuray Kolsarıc for her valuable scientific support and for her laboratory opportunity.

\section{References}

Adeyemi, K.D., Mislan, N., Aghwan, Z.A., Sarah, S.A. \& Sazili, A.Q. 2014. Myofibrillar protein profile of Pectoralis major muscle in broiler chickens subjected to different freezing and thawing methods. International Food Research Journal 21: 1089-1093.

Alarcon-Rojo, A.D. \& Janacua-Vidales, H. 2010. Physicochemical changes during freezing and thawing of poultry meat. In: Guerrero-Legarreta, I. (ed.). Handbook of Poultry Science and Technology (Volume 1: Primary processing). A John Wiley \& Sons, Inc. Publication. p. 243-261. https://doi.org/10.1002/9780470504451.ch13

Alasvand Zarasvand, S., Aminlari, M., Kadivar, M. \& Shekarforoush, S.S. 2013. A comparative study on the physicochemical, functional and protein electrophoretic pattern of ostrich meat and beef during frozen storage. Journal of Food Biochemistry 37: 237245. https://doi.org/10.1111/j.1745-4514.2011.00602.x

Ali, S., Zhang, W., Rajput, N., Ammar Khan, M., Li, C. \& Zhou, G. 2015. Effect of multiple freeze-thaw cycles on the quality of chicken breast meat. Food Chemistry 173: 808-814. https://doi.org/10.1016/j.foodchem.2014.09.095

AOAC 2010. Official Methods of Analysis of AOAC International. Washington, DC, USA.

Bao, Y., Boeren, S. \& Ertbjerg, P. 2018. Myofibrillar protein oxidation affects filament charges, aggregation and water-holding. Meat Science 135: 102-108. https://doi.org/10.1016/j.meatsci.2017.09.011 
Baron, C.P., Kj/Ersgård, I.V., Jessen, F. \& Jacobsen, C. 2007. Protein and lipid oxidation during frozen storage of rainbow trout (Oncorhynchus mykiss). Journal of Agricultural and Food Chemistry 55: 8118-8125. https://doi.org/10.1021/jf070686f

Benjakul, S., Seymour, T.A., Morissey, M.T. \& An, H. 1997. Physicochemical changes in pacific whiting muscle proteins during iced storage. Journal of Food Science 62: 729-733. https://doi.org/10.1111/j.1365-2621.1997.tb15445.x

Candogan, K. 2000. Bacterial Starter Cultures, Aging and Fermentation Effects on Some Characteristics of Fermented Beef Sausages. Ph.D. Thesis, Clemson University, Clemson, SC.

Chan, J.T.Y., Omana, D.A. \& Betti, M. 2011. Effect of ultimate $\mathrm{pH}$ and freezing on the biochemical properties of proteins in turkey breast meat. Food Chemistry 127: 109-117. https://doi.org/10.1016/j.foodchem.2010.12.095

deMan, J.M. 1999. Water. In: Principles of Food Chemistry. Maryland, USA: Aspen Publishers, Inc. https://doi.org/10.1007/9781-4614-6390-0

Estevez, M. 2011. Protein carbonyls in meat systems: a review. Meat Science 89: 259-279. https://doi.org/10.1016/j.meatsci.2011.04.025

Farouk, M. \& Swan, J. 1998. Effect of muscle condition before freezing and simulated chemical changes during frozen storage on the $\mathrm{pH}$ and color of beef. Meat Science 50: 245-256. https://doi.org/10.1016/S0309-1740(98)00036-9

Gornall, A.G., Bardawill, C.J. \& David, M.M. 1949. Determination of serum proteins by means of the biuret reaction. The Journal of Biological Chemistry 177: 751-766.

Guyon, C., Meynier, A. \& de Lamballerie, M. 2016. Protein and lipid oxidation in meat: A review with emphasis on high-pressure treatments. Trends in Food Science and Technology 50: 131-143. https://doi.org/10.1016/j.tifs.2016.01.026

He, Y., Huang, H., Li, L., Yang, X., Hao, S., Chen, S. \& Deng, J. 2018. The effects of modified atmosphere packaging and enzyme inhibitors on protein oxidation of tilapia muscle during iced storage. LWT-Food Science and Technology 87: 186-193. https://doi.org/10.1016/j.Iwt.2017.08.046

Hsieh, C.W., Lai, C.H., Ho, W.J., Huang, S.C. \& Ko, W.C. 2010. Effect of thawing and cold storage on frozen chicken thigh meat quality by high-voltage electrostatic field. Journal of Food Science 75: M193-M197. https://doi.org/10.1111/j.1750-3841.2010.01594.x

Huang, L., Liu, Q., Xia, X., Kong, B. \& Xiong, Y.L. 2015. Oxidative changes and weakened gelling ability of salt-extracted protein are responsible for textural losses in dumpling meat fillings during frozen storage. Food Chemistry 185: 459-469. https://doi.org/10.1016/j.foodchem.2015.04.025

Huff-Lonergan, E. \& Lonergan, S.M. 2005. Mechanisms of water-holding capacity of meat: the role of postmortem biochemical and structural changes. Meat Science 71: 194-204. https://doi.org/10.1016/j.meatsci.2005.04.022

Laemmli, U.K. 1970. Cleavage of structural proteins during the assembly of the head of bacteriophage T4. Nature 227 : 680 . https://doi.org/10.1038/227680a0

Lee, Y.S., Saha, A., Xiong, R., Owens, C.M. \& Meullenet, J.F. 2008. Changes in broiler breast fillet tenderness, water-holding capacity, and color attributes during long-term frozen storage. Journal of Food Science 73: E162-168. https://doi.org/10.1111/j.1750-3841.2008.00734.x

Leygonie, C., Britz, T.J. \& Hoffman, L.C. 2012. Impact of freezing and thawing on the quality of meat: review. Meat Science 91: 93-98. https://doi.org/10.1016/j.meatsci.2012.01.013

Lombardi-Boccia, G., Martinez-Dominguez, B. \& Aguzzi, A. 2002. Total heme and non-heme iron in raw and cooked meats. Journal of Food Science 67: 1738-1741. https://doi.org/10.1111/j.1365-2621.2002.tb08715.x

Lund, M.N., Heinonen, M., Baron, C.P. \& Estévez, M. 2011. Protein oxidation in muscle foods: a review. Molecular Nutrition \& Food Research 55: 83-95. https://doi.org/10.1002/mnfr.201000453

Morzel, M., Gatellier, P., Sayd, T., Renerre, M. \& Laville, E. 2006. Chemical oxidation decreases proteolytic susceptibility of skeletal muscle myofibrillar proteins. Meat Science 73: 536-543. https://doi.org/10.1016/j.meatsci.2006.02.005

OECD/FAO 2018. Meat. In: OECD-FAO Agricultural Outlook 2018-2027. p. 149-162. https://doi.org/10.1787/agr_outlook-2018-9-en

Sarma, J., Vidya Sagar Reddy, G. \& Srikar, L.N. 2000. Effect of frozen storage on lipids and functional properties of dressed Indian oil sardine (Sardinella longiceps). Food Research International 33: 815-820. https://doi.org/10.1016/S0963-9969(00)00077-6

Soyer, A., Özalp, B., Dalmış, Ü. \& Bilgin, V. 2010. Effects of freezing temperature and duration of frozen storage on lipid and protein oxidation in chicken meat. Food Chemistry 120: 1025-1030. https://doi.org/10.1016/j.foodchem.2009.11.042

Srinivasan, S. \& Hultin, H.O. 1997. Chemical, physical, and functional properties of cod proteins modified by a nonenzymic freeradical-generating system. Journal of Agricultural and Food Chemistry 45: 310-320. https://doi.org/10.1021/jf960367g

Utrera, M. \& Estévez, M. 2013. Oxidative damage to poultry, pork, and beef during frozen storage through the analysis of novel protein oxidation markers. Journal of Agricultural and Food Chemistry 61: 7987-7993. https://doi.org/10.1021/jf402220q

Utrera, M., Morcuende, D. \& Estévez, M. 2014. Temperature of frozen storage affects the nature and consequences of protein oxidation in beef patties. Meat Science 96: 1250-1257. https://doi.org/10.1016/j.meatsci.2013.10.032

Van Laack, R.L. 1999. The role of proteins in water-holding capacity of meat. In: Xiong, Y., Ho, C. \& Shahidi, F. (eds.). Quality Attributes of Muscle Foods. New York: Kluwer Academic / Plenum Publishers. p. 309-318. https://doi.org/10.1007/978-1-4615-4731-0_21

Xia, X., Kong, B., Liu, Q. \& Liu, J. 2009. Physicochemical change and protein oxidation in porcine Longissimus dorsi as influenced by different freeze-thaw cycles. Meat Science 83: 239-245. https://doi.org/10.1016/j.meatsci.2009.05.003

Zakrys, P.I., Hogan, S.A., O'Sullivan, M.G., Allen, P. \& Kerry, J.P. 2008. Effects of oxygen concentration on the sensory evaluation and quality indicators of beef muscle packed under modified atmosphere. Meat Science 79: 648-655.

https://doi.org/10.1016/j.meatsci.2007.10.030

Zhang, W., Xiao, S. \& Ahn, D.U. 2013. Protein oxidation: Basic principles and implications for meat quality. Critical Reviews in Food Science and Nutrition 53: 1191-1201. https://doi.org/10.1080/10408398.2011.577540 